\title{
Tissue Suppression
}

National Cancer Institute

\section{Source}

National Cancer Institute. Tissue Suppression. NCI Thesaurus. Code C151965.

Any of various techniques that allow the imaging of a body part while suppressing signals coming from a selected tissue. 